\title{
Self-Survey at Russell Sage College Library
}

This is the substance of a report prepared for the trustees of Russell Sage College by the librarian of the college.

INCREASING DEMAND for the type of serv1 ice that only professionally trained librarians can give; drastic cuts in a budget for student help; and efforts to place a library staff on equivalent financial footing with teaching faculty of similar rank, training, experience, and responsibility, have resulted recently in a prolonged scrutiny of the Russell Sage College Library, which has continued intermittently throughout one academic year.

Coincidental with attempts to find solutions for the threefold problem occurred a conversation with one of the administrators of the institution. This conference emphasized a growing conviction that powerful obstacles to satisfactory faculty status were an incomplete understanding of the educational aspects of a college library program and, more particularly, little knowledge of what each staff member contributes to that program. A report on job specifications was indicated, and, since through the American Library Association classification and pay plans there was available a new method ${ }^{1}$ of measuring libraries more carefully than had been possible hitherto, it seemed expedient to make a self-survey at this time.

In October 1943, with two other local

1 American Library Association. Board on Salaries, Staff, and Tenure. Classification and Pay Plans for Libraries in Institutions of Higher Education. Chicago, A.L.A., 1943. libraries, the staff was given a day's instruction in the War Manpower Commission's Training-Within-Industry Job Methods program, so invitingly reported in an article by Mrs. Gates in $1943 .^{2}$

There followed a series of staff meetings at which each member read aloud an analysis of a piece of library routine that was her particular responsibility. Next came questions and criticism from other staff members, often resulting in the elimination of unimportant activities and not infrequently leading to the reworking of an entire process.

Every routine function of the library was so challenged, with somewhat startling results. Duplication of information was revealed as the heaviest offense against efficiency. Date of purchase, price, and source of books had for years been unquestioningly recorded in three places, for no known reason. Separate shelf-list cards for special gift collections had been exceedingly useful when gift exhibits were set up, but unbiased examination forced admission that much more time and money went into making those shelf-list cards than could possibly be balanced by time that might be consumed in searching gift records, should gifts be displayed at irregular intervals.

No one had ever thought of typing a "g" on a shelf-list card instead of the word "gift" nor of substituting "FLG" for the long words "Friends of Library gift." For

2 Gates, Frances C. "Job Methods Training in Libraries." Wilson Library Bulletin 18:30-33, September 1943 . 
at least three years there had been appeals for another truck, particularly for carrying heavy magazines to storage. Not until application of job methods training procedures was a truck realized to be standing practically immobile behind one of the service desks. It was, of course, a simple matter to buy a set of low shelves resembling the truck and so release it for other work.

\section{Policies Examined}

Similar methods were used to examine library policies as well as routines. Given objective scrutiny, fine rules for pamphlets and periodicals were found to be entirely unreasonable and indefensible and were consequently revised. Inconsistencies in interlibrary loan policy with an affiliated hospital were corrected.

An inevitable result of such careful and painstaking overhauling was a thoroughly revised Staff Manual, ready in time for the annual practice student from a nearby library school.

Since Russell Sage College is a degreeconferring four-year institution, the second volume of Classification and Pay Plans for Libraries in Institutions of Higher Education $^{3}$ was used as the measuring device. Directions for procedure as outlined in the plans ${ }^{4}$ were followed. The service load for the library was calculated by translating the number of faculty and underclass and upperclass students into units of service. The 1943-44 registration figures were used. The library was found to carry I 386 service units and to belong to Class II, standards for which are listed so explicitly ${ }^{5}$ that it was relatively simple to measure staff organization, qualifications and salaries of staff members, annual expenditures, book stock, hours of service, and staff working conditions.

${ }^{3}$ American Library Association. Board on Salaries, Staff, and Tenure. Op. cit., v. 2.

Ibid., p. xix-xxxii.

I Ibid., p. 3, 4.
To familiarize the administration thoroughly with library participation in the educational program of the college, complete memoranda of job specifications seemed imperative. First there was made a job analysis of all professional and clerical positions, using for the purpose the checklist recommended. ${ }^{6}$ The functional arrangement of form was exceedingly valuable for a continued scrutiny of the Russell Sage library. A number of processes were obviously out of their proper departments, and several small jobs could be performed more efficiently if shifted. A staff of five professional and one and one-half clerical workers, exclusive of student help, cannot be highly departmentalized, nor can all work be divided on a strictly functional basis. One glaring example of overlapping still exists in bindery preparation, logically belonging to the heavily pressed catalogers but actually handled by the person in charge of circulation and reference, in an effort to equalize work loads.

A job analysis for a one- or two-week period may take no account of important tasks performed only at intervals throughout the year. When such material was added to the checklists, complete pictures of each position emerged. The data were then used as a basis for classifying each position, and here again it is evident that a small library cannot completely conform to patterned organization. To illustrate, our assistant librarian, being in charge of work with the public, is really a combination of chief reference and chief circulation librarians, as specified for Class II libraries. ${ }^{7}$

\section{Job Specifications}

When all staff members were measured by the professional and personal qualifica-

6 Ibid., p. 114-21.

7 Ibid., p. 36,56 . 
tions $^{8}$ listed as essential to the positions they hold, there remained the difficult task of writing job specifications for each library position. It will be remembered that one of the primary reasons for undertaking the whole program of self-survey was to explain to the college administration how the work of each person on the staff contributes to the educational program of the entire institution. To describe library positions, keeping such a purpose in the foreground, doing it in nontechnical terms, and making the descriptions reasonably short and at the same time explicit, is no simple undertaking. The examples given in the A.L.A. plans ${ }^{9}$ were thought to be too gen-

8 Ibid., p. I 5.I I I

Ibid., p. 15-101. eral in character to be intelligible to a nonlibrarian. However, they were used as models for considerably more specific accounts of each job.

Finally, the entire survey was described fully in the form of a report to the board of trustees. Conclusions emphasize the fact that an entirely new method of measuring the library shows results in complete agreement with other studies submitted within the last five years. The inevitable recommendation is a considerably increased budget for books and salaries, without which further development of library service to the college will be limited to what the staff can achieve on present resources of time and money.

\section{The Training of Divisional Reading Room Librarians}

\section{(Continued from page 7)}

ministrative realities, as anyone very closely associated with universities can testify.

If it is to be assumed that the divisional librarian is to have some definite instructional function, then obviously he or she must be able to teach. To be a professor one must profess. This may take several forms : first, straight classroom teaching in a subject; second, teaching the bibliographic apparatus techniques for a special field; third, a semitutorial arrangement worked out to fit in with the needs of the faculty in a department. Common to all, though, is the fact that the librarian must know a good deal about at least one subject area, regardless of what else he knows.

\section{Summary}

The essence of this discussion is that the pattern of divisional library service is not yet set. Library schools have a great opportunity for leadership by striking out into new curricula that will provide librarians capable of establishing a pattern of service for divisional librarians. 